\title{
Restrictions on the Rights of Landowners and Entrepreneurs in Turkestan in the Early Years of Soviet Rule
}

\author{
Sharofiddin Kozimjonogli Khoshimjonov \\ PhD Student, Specialty of "History of Uzbekistan”, Andijan State University, Uzbekistan
}

http://dx.doi.org/10.18415/ijmmu.v8i8.2978

\begin{abstract}
The article analyzes the policy of persecution and restrictions imposed on Turkestan's landowners and entrepreneurs in the early years of Soviet rule. It contains information on the means of production owned by the owners, the confiscation of land and other property in favor of the state, the political restrictions on the business community.
\end{abstract}

Keywords: Provisional Government; Bolsheviks; Soviet Government; Agrarian Policy; Nationalization; Land Decree; Landowners; Entrepreneurs; Wealthy Farms; Voting Rights; "Injustices"

\section{Introduction}

The Provisional Government, which came to power in February 1917 as a result of the democratic revolution in Petrograd, passed laws aimed at guaranteeing human rights and freedoms in the territory of the Russian Empire. The slogans of freedom, equality, independence, and the democratic changes that were proclaimed after the February Revolution were well received in colonial Turkestan as well as in the oppressed peoples of the empire. The short-lived Provisional Government was in no hurry to make a final decision on which path to take in property, including private property, and in relations with landlords. In former Tsarist Russia, an agrarian state, the land issue came to the fore. Different proposals have been put forward by different political parties to address the agrarian issue. While the Cadets (Constitutional Democrats) party proposed to prioritize private ownership of land, the SocialistRevolutionaries (ESR) argued that the distribution of land should be based on the norm of land cultivation, and that land ownership should be in the hands of the state. While the Mensheviks intended to municipalize the land, the Bolsheviks advocated the seizure of all property, including land, from the more radical large and medium-sized landowners, the transfer to the state land fund, and the establishment of collective farms (Golovanov: 2007, p. 39).

The interim government has argued that the land issue, in general, should be regulated through well-thought-out reforms. The bourgeois class that emerged in Turkestan also sought to expand trade and economic relations. The populist calls of the Bolsheviks, the promises to take the lands from the rich to the poor, intensified the radical mood in the central regions of Russia and divided the population in two. Eventually the October coup took place and the totalitarian regime of the Soviets was established.

\section{The Main Findings and Results}

From the very first days of the Soviet regime, it began to pursue a policy against private property, the owners. The influence of large landowners, industrialists, new indigenous and European nationalists and entrepreneurs in society was strong, which was one of the most difficult problems for the Bolsheviks. They saw the property class as the main opposing force in the implementation of their policies and interpreted them as an exploiting-oppressive class. Calling them "hostile elements", "rich-exploiters", "rich-ear elements", "speculators", "bourgeois representatives", "capitalists" and so on, the main task was 
to arouse hatred against them in the general public. The documents stipulated that the owners and entrepreneurs, commonly referred to as "rich", were seen only as a class that was harmful to society, and that they should be abolished and the power of the working people established over them. This goal was also reflected in the laws of the Soviet government. This policy was initially reflected in the restriction of certain rights of owners, the confiscation of property.

The nationalization of industrial enterprises in Turkestan was carried out faster than in Central Russia. The industries of great importance for the defense and the national economy in the country were first and foremost the property of the Soviet state. Leather and metal processing plants and workshops in Tashkent, pasta factory, Asaka, Kattakurgan, Kokand, Andijan, Skobelev (Fergana), power plants in New Bukhara, woodworking enterprises and warehouses at Tashkent, Kokand, Samarkand and Gorchakovo stations, brick factories in Samarkand and Jizzakh, Kokand and the silkworm seed factories in Skobelev, all the wineries, wool processing, irrigation enterprises, and transport societies in Turkestan were confiscated in favor of the state as early as the first half of 1918-1919 (History of the Uzbek SSR: 1971, p. 182).

The Decree "On Land" adopted on October 26, 1917 provided for the transfer of large estates, lands of kings and religious organizations, along with animate and inanimate inventory, farm buildings to rural land committees. This led, on the one hand, to the abolition of very large land holdings with low levels of efficiency, and on the other hand, to the subsequent termination of both medium and small land tenure in the process, and to the transfer of all lands to collective farms. In the end, the land passed from the hands of a large landowner to another state. As the Bolsheviks had promised, the land did not belong to the peasant anyway, and the content remained the same as the form changed. This was clearly reflected in the "Basic Law on the Transformation of Land into Common Property", adopted on January 27, 1918. Land has been excluded from market relations. Although the land was officially said to be owned only by those who could work on their own or with the strength of their families, along with agricultural communes, companies, and rural communities, virtually all rural workers became workers on statedependent kolkhozes and sovkhozes(Socialist reorganization of agriculture in Uzbekista: 1962, p. 39). Under the leadership of local party organizations, the Soviets of Peasants' Deputies continued the agrarian reforms that had begun in the villages, confiscating large tracts of land, and registering so-called "laborless farms". For example, in 1918, only in 11 volosts of the Tashkent district, 174 unemployed farms with 12,000 desiatinas were registered, and most of them were confiscated. In the great fortress county, about 3,000 desiatins of land were taken into account, and more than 1,560 desiatins were confiscated and distributed to landless peasants. In Skobelev district 12,315 desiatins, in Kokand district 2,235 desiatins of land were taken into account and distributed to poor farms(Aminova: 1983, pp. 144145). Worst of all, the methods of struggle against the "rich-ears" were also aimed at the middle class. They, too, were deprived of the right to vote as owners, their property confiscated, and in some cases physically destroyed.

Later, the constitution of the Russian Soviet Federative Socialist Republic, adopted in 1918, which served as the basis for the constitution of the republics of the Soviet Union, including the Turkestan ASSR, referred to the "brutal abolition of the exploiter". In particular, Article 3 of this constitution abolishes the form of private ownership of land. Factories and plants, manufacturing enterprises, and all forms of property in general were to be transformed into state property. Article 23 explicitly states that "the Socialist Federal Republic of Russia shall deprive individuals and certain groups of their rights that are detrimental to the interests of the socialist revolution in the general interests of the workingclass"(http://constitution.garant.ru/history/ussrrsfsr/1918/chapter/dc8ac69baa61b785e8510c75c9 $714 \mathrm{f} 10 /)$.

According to Article 65, employees and users of labor, business owners and shareholders, and private traders were deprived of the right to vote (http://constitution.garant.ru/history/ussrrsfsr/1918/chapter/0257344edab1af5a18841e154a3312f4/). Instead of protecting all categories of citizens, which is one of its main tasks, the state tried to turn the classes against each other, to provoke, and thus to create a general mood against the property class, and in a sense it did so.

The Constitution of the Turkestan ASSR, adopted in September 1920 on the model of the Constitution of the Russian Soviet Federative Socialist Republic, also deprived the entrepreneurial and property classes of a number of rights (Central Archive of Uzbekistan). Article 85, Section 5 of the 
Constitution, entitled "Active and Passive Voting Rights" (Participation in elections by nominating one's own candidate is a passive suffrage, and an active suffrage is the right to vote for one's proxy in elections), states that members of both sexes who have reached the age of 18 have the right to vote and stand for election, regardless of their religion, nationality or location. According to the following paragraphs of this article: a) persons applying for employment for profit; (b) Persons living on unearned benefits, such as interest on capital, income from enterprises, income from property, etc.; c) private traders, trade and commercial intermediaries were deprived of the right to vote (Central Archives of Uzbekistan).

In the USSR, which was formed as a result of national-territorial delimitation in late 1924, the previous policy against landowners was further intensified. Therefore, on the model of the Constitution of the Constitution of the Russian Soviet Federative Socialist Republic adopted in 1925, the Constitution of the USSR was adopted in March 1927 at the II Congress of Soviets of Uzbekistan. According to Articles 92-93 of Chapter 13 of Chapter 6 of the Constitution "On Elections to the Council", the Central Election Commission of the Uzbek SSR on December 12, 1927 "Guidelines for elections to the Soviets" his political rights were restricted and he was deprived of the right to vote (Rasulov, p. 210). These norms have been reinforced by many laws and regulations. At each party congress or plenum of the Central Committee of the Communist Party, of course, the "expulsion of hostile elements" in the Soviet and party bodies, in particular, the expulsion of former industrialists, the rich and entrepreneurs, were discussed and separate decisions were made.

At the Second Plenum of the Central Committee of the Communist Party of the Soviet Union, held on April 8-11, 1925, it was decided to publish a full list of persons deprived of the right to vote and stand for election in accordance with the Constitution before the elections to the entire Soviet apparatus (The Communist Party of Uzbekistan: 1987, p. 60). In addition, it was proposed to clean up the "foreign elements" in the Soviet apparatus and hold re-elections to the Soviets. Mirzachul district was cited as an example, where the Soviets were occupied by the rich, mullahs and other "hostile elements", and a reelection was held in the lower Soviet apparatus to replace the poor and middle peasants and workers.

The party grew from a policy of restricting property rights to gradually persecuting them and, if necessary, sweeping them out of public life. This was reflected in the party's decisions in subsequent resolutions. At the IV Plenum of the Central Committee of the Communist Party of Uzbekistan (b) held in Samarkand on September 24-28, 1925, the issue of "Results and Prospects for the Rehabilitation of the Soviets in Uzbekistan" was considered on the agenda. It was noted at the plenum that in reviving the work of the lower Soviet apparatus of Uzbekistan, the regions can be divided into two types. It was noted that the first type included well-organized lower Soviet apparatus and the second type included Soviet apparatus occupied by former regime officials, the rich, property owners, merchants, and "anti-Soviet elements" in general, such as Zarafshan, Kashkadarya, and Surkhandarya(The Communist Party of Uzbekistan: 1987, p. 82).

The plenum called for a campaign of ruthless cleansing of the Soviets from the rich and landlords in such areas (The Communist Party of Uzbekistan: 1987, p. 92). In addition, the Bolsheviks made it a necessary task to intensify the class struggle in the countryside and to direct the activities of the batrak, the poor and the middle class against the rich and the landowners. Thus, the class struggle was artificially intensified in the villages as well.

On November 22-30, 1925, at the second congress of his Communist Party (b) in Samarkand, he called for "the completion of the purge of the Soviets from the rich and the clergy through re-elections; The constitution provides for the constant monitoring and exposure of "alien elements" in the Soviet authorities and the party apparatus, who have no right to participate in elections, and for exemplary trials of the wealthy and property owners who infiltrated the Soviet Union (The Communist Party of Uzbekistan: 1987, p. 155).

It is clear from the content of the decision that the issuance of practical instructions to initiate repressions against the landlord class began as early as 1925. Under the pretext of purging the lower Soviet bodies under the leadership of the party, the registration of all entrepreneurs and landowners, as a result of which the confiscation of their property, land and commercial and residential buildings, production facilities at public expense became widespread. It is self-evident that whoever was persecuted 
by the party would become a disenfranchised citizen. Like other systems, the judiciary has in practice become the executor of party tasks.

In 1926, when the re-elections were in full swing, the expulsion of the rich, the ears, and the merchants from the Soviets became widespread. Even the children of the property class were not included in the youth organizations. Representatives of this class were ostracized and persecuted. It should be noted that on October 3-8, 1926, in order to further expand the scope of elections at the IV joint plenum of the Central Committee of the Communist Party of Uzbekistan and the Central Election Commission of the USSR, 7 oblasts, 23 districts, 241 volosts were divided into 10 districts and 87 districts. The proposal to be considered was considered. it was decided to carry out these administrative changes by February 1927 (before the election - Sh.H.) (The Communist Party of Uzbekistan: 1987, p. 272).

According to the elections of early 1927, the composition of the Soviets was renewed by $70-80 \%$ (The Communist Party of Uzbekistan: 1987, p. 288). Propaganda spread throughout the country. The leaders of the republic at that time also expressed their views from the position of the Bolsheviks in their speeches. "The rich will not be given any tax breaks, but will be given more (tax increases - Sh.Kh.), will not participate in cooperatives, will not be allowed near the council, will not be given any assistance provided by the government to the people", "Soviet law has the right to vote and stand for election" People who are not rich, such as the rich, the poor and so on, should not be involved in the elections", he said (Oxunboboev: 1976, p. 76).

Practical measures were taken in this direction, and in the election campaign of 1925-1926, 27,453 people were deprived of the right to vote. However, party and government officials noted that there had been delays in the process, and that as a result of the elections, property owners and entrepreneurs were more likely to be elected to the Soviets. Therefore, in the re-election campaign of 1926-1927, appropriate instructions were given to further increase the list of "deprived". As a result, 33,204 people were disenfranchised during the 1926-1927 election campaign. The majority of those deprived of the right to vote were the property class, traders and clergy, in particular, $19.2 \%$ of the total number of those deprived of the right to vote, or 6,375, were traders (Oxunboboev: 1976, pp. 263-264).

In 1929, the number of voters in Samarkand was 86,981, of which 8,772 were disenfranchised. This was $11.2 \%$ of the total number of voters. Most of them were "rich-ear" elements, landowners and priests (Central Archive of Uzbekistan). After the strengthening of Soviet power in Uzbekistan, the deprivation of the economic basis of landowners, factory owners, industrialists, traders and entrepreneurs, and their de facto liquidation, the norms restricting their rights were removed from the constitution and laws. According to Article 135 of the new Constitution of the USSR of November 25, 1936, the list of those deprived of the right to vote included only those who were mentally retarded and deprived of the right to vote by a court decision (www.constitution.garant.ru/history/ussr-rsfsr/3865986).

Violation of property rights is not limited to deprivation of the right to vote, but also to deprivation of a number of other socio-political and civil rights; prohibitions such as not admitting them to various associations and public organizations were also enshrined in law. They are free to work, to work in fair working conditions; the right to social security; were deprived of medical care as well as education. At the next plenum of the Central Committee of the RCP (b) in August 1921, this issue was considered and a number of decisions were made.

At the same time, they were deprived of the right to join the union "users of hired labor for income, interest on capital, unemployed persons on the basis of profits from an industrial enterprise or property, private traders and trade intermediaries" in accordance with paragraphs "a", "b", "c" of Part 8 of the "Charter of the Union of Working Peasants", adopted in the fall of 1920 (Socialist reorganization of agriculture in Uzbekistan: 1962, p. 3997).

According to Section 15 of the Law on the Union of Koshchi, adopted on March 15, 1922, the above categories could not be members of the organization(Central Archive of Uzbekistan). However, it was not possible not to include owners in associations and public organizations in the manner prescribed by law. Because even in the 1920s, the influence of landowners and entrepreneurs, merchants, was still high, and in some places, this class became part of the local Soviets. For such Soviets, "alien elements" were removed from the Soviets, and "cleansing" was carried out in the party and Soviet offices, which 
were completely excluded from the organizations. For example, a report on the activities of the Koshchi Union for the period from September 1925 to March 1926 emphasized that the "rich and merchants" were holding back the organization, that they should be expelled from the organization, and provided information on the "cleansing". According to him, 1583 people were expelled from the organization in the Tashkent regional branches of the organization, of which 858 were "rich exploiters" and 398 were traders. In Samarkand, 1,159 people were expelled from the organization, including 233 "rich exploiters" and 185 traders (Socialist reorganization of agriculture in Uzbekistan: 1962, pp. 524-525).

\section{Conclusion}

Thus, from the first years of Soviet rule, the Bolshevik government in Turkestan began a fierce struggle against private property and entrepreneurship. Under the guise of protecting the interests of the poor working people, the Bolsheviks practically destroyed the centuries-old forms of ownership and land tenure in Turkestan. Large sections of landowners and entrepreneurs were declared by the party-Soviet authorities as "foreign elements" and "exploiting classes" and a sharp struggle began against them. Production facilities, land, water, agricultural equipment, and food stocks in the hands of the owners were forcibly confiscated, and their owners were persecuted.

\section{References}

Golovanov A. A., SaidovI. M. (2007) Dekhkanism (Farmers) of Uzbekistan at the historical turn of the second half of the 19th - first third of the 20th centuries. Samarkand.

History of the Uzbek SSR.4 volumes.Vol 3.1917-1937.Editor-in-Chief I.M.Muminov.Tashkent:Fan,1971.

Socialist reorganization of agriculture in Uzbekistan (1917-1926). (1962) Collection of documents. Tashkent: Publishing house. AcademyofSciencesoftheUzSSR.

Aminova R. Kh. (1983) Agrarian policy of the Soviet government in Uzbekistan (1917-1920). Tashkent: Publishing house of the Academy of Sciences of the Uzbek SSR.

http://constitution.garant.ru/history/ussr-rsfsr/1918/chapter/dc8ac69baa61b785e8510c75c9714f10/

http://constitution.garant.ru/history/ussr-rsfsr/1918/chapter/0257344edab1af5a18841e154a3312f4/

Central Archive of Uzbekistan, R-17 fund, list 1, case 805.

Rasulov B. (2012). Political repression and the situation of exiled peasants in the process of collectivization in Uzbekistan (1929-1959). Tashkent: Sharq.

The Communist Party of Uzbekistan in resolutions and decisions of congresses and plenums of the Central Committee (1925-1937). (1987) Volume 1. Collection of documents. Moscow: Politizdat.

OxunboboevYuldosh. (1976) Selected works. Tashkent: Uzbekistan.

Central Archive of Uzbekistan, fund R-86, list 1, case 6167.

www.constitution.garant.ru/history/ussr-rsfsr/3865986...

Socialist reorganization of agriculture in Uzbekistan (1917-1926). (1962) Collection of documents. Tashkent: Publishing house. Academy of Sciences of the UzSSR.

\section{Copyrights}

Copyright for this article is retained by the author(s), with first publication rights granted to the journal.

This is an open-access article distributed under the terms and conditions of the Creative Commons Attribution license (http://creativecommons.org/licenses/by/4.0/). 